\title{
Rethinking the Larger Pattern of the American Interest in the Arab Gulf
}

\author{
Hasnan Bachtiar ${ }^{1}$ \\ ${ }^{1}$ Faculty of Islamic Studies, University of Muhammadiyah Malang, Indonesia, bachtiar@umm.ac.id
}

\begin{abstract}
This article aims to evaluate the larger pattern of American interest in the Arab Gulf, whether it is based on ideological or economic interest. Consequently, it encourages to deal with conceptual analysis of various data of the social, economic and political interlinks and special topics that have been significantly proposed in the state policy. Due to this article does not put merely on a specific issue and one of dominant factors conditioning the American interest in the region, it claims the distinctiveness of the article. Methodologically, it has debts the significant of the theory of rational choice in interpreting the relevant data. It argues that the US foreign policy represents two larger directions of its interest: economy and ideology. Both have linked together and the interrelation have determined and have been determined by strategic culture of the states in the region and its complexities covering all national, interstate, regional, broader regional (Middle East) and global levels. It also arguably states that there is no single interest that can claim to be the most dominant, but it has remained highly dynamic and has demonstrated multiple complexities of the interest in which they are represented by issues of oil, war on terrorism, nuclear weapon and Israel.
\end{abstract}

Keywords: American interest; Arab Gulf; war on terrorism; nuclear weapon; Israel.

\begin{abstract}
ABSTRAK
Artikel ini bertujuan mengevaluasi apakah pola umum kepentingan Amerika di Kawasan Teluk Arab didasarkan kepada kepentingan ideologis ataukah ekonomis. Karenanya, artikel ini menguji berbagai data yang ada dan menginterpretasikan hubungan-hubungan kompleks persoalan sosial, ekonomi dan politik, serta berbagai topik khusus yang secara signifikan seringkali diajukan di dalam kebijakan negara. Karena artikel ini tidak menitikberatkan pada pembahasan satu isu yang spesifik atau faktor yang dominan yang menentukan kebijakan suatu negara di kawasan, maka artikel ini mengklaim itulah yang membuatnya berbeda. Secara metodologis, artikel ini memanfaatkan pentingnya teori pilihan rasional dalam menafsirkan berbagai data yang relevan. Artikel ini menyatakan bahwa kebijakan luar negeri Amerika di kawasan merepresentasikan dua tujuan umum yakni kepentingan ekonomi dan ideologi. Keduanya terhubung satu sama lain, saling mempengaruhi dan saling bergantung kepada kultur strategis negara-negara di kawasan, serta juga oleh kompleksitas mengenai persoalan domestik suatu negara, antar negara, regional, regional yang lebih luas (Timur Tengah) dan global. Artikel ini secara argumentatif menyatakan bahwa kebijakan luar negeri Amerika tidaklah tunggal dan tidak dapat diklaim sebagai yang paling dominan, namun sebenarnya kebijakan tersebut sangat dinamis dan menunjukkan adanya kompleksitas yang berlipat-lipat, terutama yang direpresentasikan isu-isu mengenai minyak, perang terhadap terorisme, senjata nuklir dan Israel.
\end{abstract}

Kata Kunci: Kepentingan Amerika; Teluk Arab; perang melawan terorisme; senjata nuklir; Israel. 


\section{Introduction}

On Saturday, April 14th 2018 was the moment when the United State (US) President, Donald Trump had declared and launched offensive airstrikes to the Syrian military headquarter in Douma, Damascus. In his condemnation, he mentioned that Assad regime should take responsibility over using chemical weapons in war against his rivals that had also disastrously attacked civilians. ${ }^{1}$ In spite of the fact that President Assad and Russian President Vladimir Putin condemned back to the US attack, American elites several days later had insisted to argue that it is totally a right thing to attack them and their backers. ${ }^{2}$ In the warfare situation, however, there is no right or wrong, but rather the possibility of who will emerge as a winner of this cruel and inhumane competition. In this context, indeed, the law of "kill or be killed" has occurred.

A lot of eyes across the world would see this most current event of war in Syria, although there were also numbers of others that had happened during the last couple of the centuries. They would highly agree that all those wars had undertaken due to certain interests. In short, they are curious to know the reason why among states had fought each other? Most of them and also scholars have offered opinions, although those are not always representing valid things. This phenomenon shows a relative character of

1 Chris Graham and Ben Riley-Smith, "Syria airstrikes: US warns it is 'locked and loaded' if Assad uses chemical weapons again," The Telegraph, April 14 , 2018, https://www.telegraph.co.uk/news/2018/04/14/syriaairstrikes-donald-trump-set-make-announcementmilitary/.

${ }^{2}$ Andrew Roth and Hannah Ellis-Petersen, "Vladimir Putin calls US-led Syria strikes an act of aggression," The Guardian, April 14, 2018, https://www.theguardian.com/world/2018/apr/14/insu lting-russia-furious-over-syria-attacks-as-politicianlikens-trump-to-hitler. any scientific proposition that in many ways is also coloured by certain ideological claims.

The most vocal claim has stated that the American great power has worked for ideological calling. ${ }^{3}$ Accordingly, this power has been guided by less rational beliefs that underestimate and even ignore matters of profit and lost calculations. In more sarcastic expression, some scholars have claimed that it is a part of the bigger project of American imperialism. ${ }^{4}$ Undoubtedly, offering a certain thesis is important. However, it must be considered more critically before it should be recognized as a valid thing until its limitations will be found in the future. Against the claim of American imperialism, some realist scholars have argued that the US massive penetrations in the Arab Gulf region, are based on economic reasons. ${ }^{5}$ Because of oil, America as a powerful

3 Tariq Ali, The Clash of Fundamentalisms: Crusades, Jihads and Modernity (London: Verso, 2003); Edward W. Said, Culture and Imperialism (London: Vintage, 1994); Edward W. Said, Orientalism (London: Penguin Books, 2003); Edward W. Said, Covering Islam (London: Vintage, 2007); Douglas Little, American Orientalism: The United States and the Middle East since 1945 (Chapel Hill: The University of North Carolina Press, 2009); Noam Chomsky, Hopes and Prospects (London: Penguin Books, 2010).

4 Vassilis Fouskas and Bülent Gökay, The New American Imperialism: Bush's War on Terror and Blood for Oil (London: Praeger Security International, 2005); Richard H. Immerman, Empire for Liberty: A History of American Imperialism from Benjamin Franklin to Paul Wolfowitz (Princeton; Oxford: Oxford University Press, 2010).

5 Stephen C. Pelletierre, America's Oil Wars (Westport: Praeger Publishers, 2004); Thomas D. Kraemer, "Addicted to oil: Strategic implications of American oil policy," Strategic Studies Institute, U.S. Army War College, 2006. http://www.strategicstudiesinstitute.army.mil/pdffiles /PUB705.pdf; Irene L. Gendzier, Dying to Forget: Oil, Power, Palestine, and the Foundations of U.S. Policy in the Middle East (New York: Columbia University Press, 2015); Donald M. Snow, The 
force has the heart to exploit and destroy many states in the land of Arabia. While this argument has been defended as an opposition of another, the validity of both, must not be oversimplistically accepted.

In considering them, whether the American interest is based on ideological or economic interest, between them there are always complexities that have constructed. These complexities have not been only clinging to America, but also to various states in the region. This article briefly examines both propositions to know which one has stronger validity, or both of them have and relatively influencing each other. Furthermore, this article evaluates various data and interprets following their social, economic and political interlinks and special topics that have been consistently existed in the state policy. This article asserts that the American interest can be explained through two interconnected economic and ideological matters. Both have engaged each other through interrelated interplay that have conditioned and been conditioned by multiple layers of strategic culture. They have functioned simultaneously through complex processes that consistently are represented by issues of oil, war on terrorism, nuclear weapon and Israel. This article covers these special issues and discussion on their multiple layers of complexities.

\section{Conceptual Framework: Special issues of the political dynamics in the Arab Gulf}

The special issues of oil, terrorism, nuclear weapon and Israel have been decided to select are due to their dominant significance in shaping the dynamic context of the interstate relation of the US and the Arab Gulf countries. ${ }^{6}$

Middle East, Oil, and the U.S. National Security Policy (Maryland: Rowman and Littlefield, 2016).

${ }^{6}$ Robert Vitalis, America's Kingdom: Mythmaking on the Saudi Oil Frontier (Stanford, Calif: Stanford University Press, 2007); Economist Intelligence Unit, "America and the Arabs -the War Against
The main aims in discussing these special issues are to diagnose their complexities, complex relations of these complexities and to find a trajectory of conceptual and theoretical reformulations and sophistication of the larger argument of American interest in the Arab Gulf region. Accordingly, the general argument of economy as the only American interest should be critically evaluated. At the same coin, it should also be done to the argument of ideology. Both reciprocally have contributed each other through the complex process of constituting nonmonolithic American interest. In the process of constituting, it has been shaped and conditioned by various policies.

There are two kinds of policy, those are domestic or national and foreign or international policy. Both have affected each other. Making a certain decision in international level, for example, has also been affected by certain internal political situations in the state. In addition, different regimes will result different policies, although there is always a general pattern of policy that represents a continuity. The last three regimes of the American administration, George Bush, Barrack Obama and Donald Trump, each leader has his own special character in driving his policies in the Arab Gulf region. Undoubtedly, oil is important for them that explains the US economic interest.

Terrorism." The Economist (London) 362, no. 8265 (2002); Julian Borger Diplomatic editor, "US Military Chiefs Warn Israel Against Strike on Iran: Raid could Cut Off Support from America's Arab Allies Fears Attack on Nuclear Site would Worsen Unrest," The Guardian (London), 2012; Thomas A. Johnson, Power, National Security, and Transformational Global Events: Challenges Confronting America, China, and Iran (Boca Raton: CRC Press/Taylor \& Francis, 2012); Hall Gardner, Averting Global War: Regional Challenges, Overextension, and Options for American Strategy (New York: Palgrave Macmillan, 2007); John J. Mearsheimer and Stephen M. Walt, The Israel Lobby and U.S. Foreign Policy (New York: Farrar, Straus and Giroux, 2007). 
However, how to obtain this interest, it has been coloured by certain ideological interests, dependent on each style of leadership of the regime and also the dynamic strategic culture in the country.

In addition, actors in some parts of the US domestic political games - either in their executive institutions, houses of representative, circles of foreign policy "think thank", or political parties - obviously have been invited to give certain political responses which in turn, these responses should be understood as resources of internal reflections for the development of the state political strategy. It means the US, Arab Gulf states and other important states of broader regional boundaries have involved in such dynamic interactions. Accordingly, a certain policy should be considered properly following various dynamic conditions and situations.

Thus, in order to diagnose complexities of American-Arab Gulf relations, a critical discussion on themes of oil, terrorism, nuclear and Israel covers four important elements: the general pattern of policies, the enactment of policies, political implications and responses both in international and regional level and also in the broader regional level (Middle East), and conceptualization.

\section{Analysis}

\section{a. Oil matter}

The oil matter is really important for the US. If considering that it is not the most significant factor that explains the package of the argument of American interest in the Arab Gulf, it depends on the viewpoint, the perception and also historical contexts of this issue, including its continuity and discontinuity. The American oil policy in the Arab Gulf has been implemented in a complex process represented through a long period of relationships between the US and Arab Gulf states. Throughout this period there are also implications as various and dynamic responses that have come from political subjects in multiple levels. These responses, furthermore, have led to two diametrically contradictory situations, those are stability and instability. Thus, although oil is important, it has linked directly to a line of security matters.

The importance of oil for the US is generally to cover their national demands of energy supply, increase their national revenues through export-import activities, involve in driving the global oil market and also support their economic development programmes. ${ }^{7}$ To securing their oil interest, the US should also guarantee the regional security of oil producers. ${ }^{8}$ In a strategic level, militarization is one of paths that has been applied for ensuring the larger goal of the US interest.

Since the 20th century the US oil policy has undertaken in the Arab Gulf region. ${ }^{9}$ It began from the 1930s coincided with the moment of the post-"the Red Line Agreement" (1928), the US oil company had better chances to enhance their relationships with Arab Gulf states. In 1931, a branch of an American oil company discovered oil reserves in Bahrain and began production the following year. In 1937, the US-British-Kuwait company discovered oil in Kuwait, but they started exploitation after the World War II. In 1938, the Arabian American Oil Company (Aramco) discovered oil in Saudi Arabia and at that time also, the oil production began. In 1939, the Qatar Petroleum Company discovered oil, but the US started to drive their control over oil in Qatar in 1949. In 1964, oil

\footnotetext{
${ }^{7}$ Ian Rutledge, Addicted to Oil: America's Relentless Drive for Energy Security (London; New York: IB Tauris, 2005);

8 Joseph McMillan, "US interest and objectives," in The United States and the Persian Gulf: Reshaping Security Strategy for the Post-Containment Era, ed. Richard Sokolsky (Washington, DC: National Defence University Press, 2003), pp. 9-36.

9 Abdulhay Y. Zalloum, Oil Crusades: America through Arab Eyes (London: Pluto Press, 2007).
} 
reserves were discovered in Abu Dhabi and their extraction began in 1967, but the US larger involvement in Emirates business of oil developed from 1971. In 1954 Washington offered Tehran a consortium of managing Iran's oil industry, after overthrown nationalist Prime Minster of Iran Mohammad Mossadeq one year before. ${ }^{10}$

Practically, all these oil relationships between the US and Arab Gulf states have influenced the emergence of implications in terms of political dynamics in multiple levels. It brings the US to consider both a long and short term political strategy. In securing the continuity of oil exploitation and controlling regional stability, both of them should be drafted in the US long term strategy. In addition, in limiting or overthrowing resistant powers that hamper their longer term strategy, it should be programmed in a short term strategy.

The US political manoeuvre in Iran from 1950s to 1970 s had been the best evidence of the argument of complex implications due to the implementation of the securitization of the American oil policy in the region. Iranian resistances had illustrated larger political dynamics, problems of balances of powers in the region and political constellations that have involved many actors in multiple levels. ${ }^{11}$ In 1953, because of Mossadeq's political manoeuvre in nationalizing the Anglo Iranian Oil Company (AIOC), British and American intelligence services had dealt to operate a secret project of overthrowing this Iranian leader. ${ }^{12}$ It

10 Morteza Gharehbaghian, "Oil revenue and the militarisation of Iran: 1960-1978," Social Scientist 15, no. 4/5 (1987): 87-100.

${ }^{11}$ Andrew Scott Cooper, The Oil Kings: How the US, Iran, and Saudi Arabia Changed the Balance of Power in the Middle East (New York: Simon and Schuster, 2012).

12 Moyara de Moraes Ruehsen, 'Operation 'Ajax' revisited: Iran, 1953," Middle Eastern Studies 29, no. 3 (1993): 467-486. brought Shah into the throne as a new secularisttotalitarian leader. In 1978-1979, Shah had been challenged by massive mass riots and overthrown through the Iranian Revolution. ${ }^{13}$ While Iran became one of the US enemies, this situation had influenced other American allies in terms of increasing anti-American sentiments. Another anti-American entity, - though it was not in an influence of the Revolution - a radical Wahhabism had also emerged in Saudi Arabia. This radical group took part in a politicoreligious protest against the Saudi monarch and controlled over the holiest place of Islam: "Masjid al-Haram" in Makkah. ${ }^{14}$ This group had condemned the al-Saud for deviating from the purity of Islam regarding their relationships with the US, although of course there were other factors involved in.

Hence, the implementation of the American oil policy since 1940s, has resulted in political stability in certain countries and instability in others. This political stability or instability has led to more complex implications such as the raise of multiple layers of political contestation with involvements of multiple levels actors. This is indeed, all about security problems in the region. The US economic policy has shaped various characters of balances of powers in the region and influenced dynamically regional strategic culture that has mainly related to national security issues.

\section{b. War on terrorism}

The US economic policy has resulted in the initiation of another policy with more ideological nuances: "war on terrorism". This has been implemented as a response to regional

13 Karen Rasler, "Concessions, repression, and political protest in the Iranian revolution," American Sociological Review, 61, no. 1 (1996): 132-152.

14 Gwenn Okruhlik, "Networks of dissent: Islamism and reform in Saudi Arabia," Current History 101, no. 651 (2002): 22-28. 
and global dynamic changes and also as a legitimacy of securing the economic policy. ${ }^{15}$ The long history of the US political and economic expansions in the Arab Gulf region are not always perceived as good things. Sometimes, these expansions are viewed as wrong things, evil and harmful. In this context, accordingly, the emergence of anti-American sentiments is rather a kind of political resistances than terrorism. ${ }^{16}$ In fact, it had appeared coincidentally with the policy of securitisation of Islam in the name of "war on terrorism" emerged in the Post 9/11 era.

The main aim of this "war on terrorism" policy is to solve the problem of terrorism itself. More precisely, it is important for repelling American enemies that hinder the longer term American policy. In order to guarantee the American economic interest, American policy makers offer this policy to stabilize balances of powers in the region.

This policy is strongly coloured by ideological sentiments. This policy tends to objectify "Islam" as an object of securitisation. ${ }^{17}$ The reason is pretty clear that those who have become dissent groups and anti-American movements in the region are Muslims. ${ }^{18}$

\footnotetext{
${ }^{15}$ Hall Gardner, American Global Strategy and the 'War on Terrorism' (London: Routledge, 2017).

${ }^{16}$ Sabri Ciftci and Güneş Murat Tezcür, "Soft power, religion, and anti-Americanism in the Middle East," Foreign Policy Analysis 12, no. 3 (2016): 374-394; Sabri Ciftci, Becky J. O'Donnell and Allison Tanner, "Who favors al-Qaeda? Anti-Americanism, religious outlooks, and favorable attitudes toward terrorist organizations," Political Research Quarterly 70, no. 3 (2017): 480-494.

17 Clara Eroukhmanoff, "It's not a Muslim ban! Indirect speech acts and the securitisation of Islam in the United States post-9/11," Global Discourse 8, no. 1 (2018): 5-25.

${ }^{18}$ Usama Bin Laden, "Declaration of war against the Americans occupying the Land of the Two Holly Places," in Princeton Readings in Islamist Thought: Texts and Contexts from Al-Banna to Bin Laden, eds. Roxanne Leslie Euben and Muhammadiyah Qasim
}

Fighting against them is meaning against Islam. It is quite similar argument that has been claimed by terrorists to legitimate their actions such as killing Western people (because they are Western) as Islamic. Critically, however, it can prove that the policy of securitisation of Islam is not inherently as a problem of religion itself, unless we agree with a popular recognition that every religion can potentially create terror and chaos. As a consequence, in the context of antiAmerican sentiment, Iran is also categorized as the state of terrorist (terrorising Iran). ${ }^{19}$ In fact, genealogically, the ideological foundation of the Islamist terrorism rooted in the circle of the Sunni tradition. ${ }^{20}$ Thus, it is not quite clear to identify the manipulation of the concept of terrorism, but practically, in terms of securing the American interest, any subject who is antiAmerica and involves in creating insecurity, they highly likely will be judged as a terrorist.

In the state level, almost there is no such significant resistance (against the US) to respond to this policy of the securitisation of Islam. Even American allies in the region are gaining advantages from this ideological policy in terms of enhancing their military capacity. With the threats of anti-American sentiments, either from Iran, revolutionary Shia groups, or Sunni jihadists, American allies need better military supports. To develop their military powers,

Zaman (New Jersey: Princeton University Press, 2009), pp. 436-459.

19 Zhen Jiang, "Confrontations on the issue of terrorism between Iran and the US after 1979," Terrorism and Political Violence 29, no. 2 (2017): 236-253.

${ }^{20}$ Khaled Abou El Fadl, "Islam and the theology of power," Middle East Report 221 (2001): 28-33.; Abdel Bari Atwan, Secret History of al-Qa'ida (London: Abacus Books, 2007); Aneela Sultana, "Taliban or terrorist? Some reflections on Taliban's ideology," Politics and Religion Journal 3, no. 1 (2017): 7-24. 
America has good chances to open a market of weapons. ${ }^{21}$

Through this policy, America wants to ensure the stability of the region. As a consequence, it will guarantee the American economic interest.

\section{c. Threats of nuclear proliferation}

The larger pattern of argument would say that the American economic interest has led to the emergence of the policy of national security. This policy that prevents any threat of the development of nuclear weapons (or weapons of mass destruction), is a result of larger policy and also a legitimacy of political manoeuvres. ${ }^{22}$ States that threaten the American interest, either they really have weapons of mass destruction or do not have, they would be objects of securitisation. Indeed, this way will lead to regional and global contestation.

The primary aim to intercept the nuclear proliferation is to ensure the stabilization of security in the region. This stabilization will guarantee the continuity of the implementation of the American economic interest. Another more ideal aim is to securing the global world, although this argument proposes to gain such international sympathy and support in order to make easier to fight against states that are accused of developing nuclear weapons. The objective of this strategy is to block their regional and international roles, then it will

\footnotetext{
${ }^{21}$ Anthony H. Cordesman, Bahrain, Oman, Qatar, and the UAE: Challenges of Security (New York: Routledge, 2018); Hartung, W., "Trends in major US arms sales in 2017," Security Assistance Monitor, 2018. https://securityassistance.org/sites/default/files/US\%2 0Arms\%20Sales\%202017.

22 Judith Yaphe, "Gulf security perceptions and strategies," in The United States and the Persian Gulf: Reshaping Security Strategy for the PostContainment Era, ed. Richard D. Sokolsky (Washington, DC: National Defence University Press, 2003). pp. 37-60.
}

flavour the image of the implementation of the securitisation of the development of nuclear weapons as a right-noble thing.

The policy of the securitisation of nuclear weapons has been implemented in three interrelated levels: international, regional and broader regional. In international level, the US have encouraged their allies to condemn the development of nuclear weapons. In addition, this way has been facilitated by international institution such as the United Nations (UN) that instrumentally has an active role to limit the development of nuclear, mainly in the purpose of producing the weapon of mass destruction. ${ }^{23}$ In regional level (the Arab Gulf) and broader level (Middle East), it is quite similar with the policy of securitisation of Islam, the US have attempted to implement the program of militarization in the region. It means, the US have intensified roles of their market of weapons, selling military machines, vehicles and equipment, and providing military training, although the business of spare-parts and maintenance have been monopolized by the seller. ${ }^{24}$ In a certain special case, the US have tried to infiltrate within the process of internal political contestation of the objectified state. The best example of this special case is the mass demonstration in Iran, when the US was infusing propaganda of democratization that happened in $2017 .^{25}$

\footnotetext{
${ }^{23}$ Dong Joon Jo and Erik Gartzke, "Determinants of nuclear weapons proliferation," Journal of Conflict Resolution 51, no. 1 (2007): 167-194.

24 Peyman Soleiman Pour, "The impact of Iran phobia on arms race in Persian Gulf After 2001," Journal of History Culture and Art Research 6, no. 1 (2001): 73-80.

${ }^{25}$ Marwa Eltagouri, "Tens of thousands of people have protested in Iran. Here's why," The Washington Post, January 3, 2018. https://www.washingtonpost.com/news/worldviews/ wp/2018/01/03/tens-of-thousands-of-peopleprotested-in-iran-this-week-hereswhy/?noredirect $=$ on\&utm_term $=.9 \mathrm{f} 844 \mathrm{e} 735421$.
} 
It is obviously, the implementation of this policy of securitisation of nuclear weapons has sharpened the resistance of their enemy. It has also stimulated to emerge their new enemies in the broader level, depends on interrelated contexts and political dynamics around it. In the case of Iraq-Kuwait war in 1990-1991, it invited a little "moral" support of Palestinians, although this support was useless. ${ }^{26}$ In the case of the US military invasion of Iraq in 2003, it escalated massive anti-American sentiments that broadly had spread in the region, mainly in the circle of Jihadist groups. ${ }^{27}$ Meanwhile, in the context of securitisation of Iran, it has involved Russia, other revolutionary forces that politically affiliated with Iran, such as Hizbullah. ${ }^{28}$ Indirectly, it invited also China, as the greatest power of Asia, that for the long time it has supplied military stuffs for Iran. ${ }^{29}$ If the US is too frontal in facing Russia and China, it is projected that in the future it will enhance other vast and complex political implications.

Regarding the nuclear issue, thus, it is clear that the American economic interest needs to meet its fundamental requirement of the stabilization of the regional security. However, the stabilization can also create instability. The issue of nuclear in this context is instability itself that explains both a real threat and a pretext of

${ }^{26}$ F. Gregory Gause, The Gulf war and the 1990s. The International Relations of the Persian Gulf (Cambridge: Cambridge University Press, 2010), pp. 88-135.

27 Thomas Hegghammer, "Global jihadism after the Iraq war," The Middle East Journal 60, no. 1 (2006): 11-32.

${ }^{28}$ Stephen Ellis and Andrew Futter, "Iranian nuclear aspirations and strategic balancing in the Middle East," Middle East Policy 22, no. 2 (2015): 80-93.

29 Alexander Glaser, Zia Mian, Seyed Hossein Mousavian and Frank von Hippel, "Building on the Iran deal: Steps toward a Middle Eastern nuclearweapon-free zone," Arms Control Today 45, no. 10 (2015): 14-20. political manoeuvre.

\section{d. Establishing and protecting Israeli state}

The policy of the establishment and protection of the state of Israel is the only one American interest that has not resulted from the implication of the economic policy. If this policy has been considered as the thing that represents a pure ideological interest of the US, some scholars relatively will agree with it. ${ }^{30}$ However, this Israel interest, also has significant implications for other issues such as economy and national security. The pattern that works here is, in securing the American economic interest in the region, the requirement of the regional security should be fulfilled. If this regional security is to be threatened, then it will also threaten the American national security.

The fundamental aim of this policy is to secure the establishment of the Israeli state and guarantee their security. Ideally, through this policy they wish to live together with Palestinians in a peaceful coexistent relation whereby both countries can support each other. The existence of both countries can be a pioneer of the development of the human civilization based on the wisdom of Abrahamic religions. Ideally, perhaps, it is also one of important things that has been wanted by some of the Zionist lobby in various levels of the American political structure, either in congressional houses, political parties or the circle of Zionist "think thank". ${ }^{31}$

${ }^{30}$ Charles Smith, "The Arab-Israeli Conflict," in International Relations of the Middle East, ed. Louis Fawcett (New York: Oxford University Press, 2016b), pp. 259-284.; Michael C. Hudson, "The United States in the Middle East," in International Relations of the Middle East, ed. Louis Fawcett (New York: Oxford University Press, 2016), pp. 356-379.

${ }^{31}$ Grant F. Smith, Big Israel: How Israel's Lobby Moves America (Washington, DC: Middle Eastern Policy, Inc., 2016a). 
In fact, everything that has happened in the Palestinian land is totally different from the beautiful dream that is mentioned before. While the US have supported Israel, it has influenced the political attitude of Muslim countries due to the massive widespread human suffering and crisis. However, it has not urged the US to end their policy to support Israel. In this context, according to popular ideological perception in Muslim countries, Israel is an imperialist, a conflict maker, a creator of large numbers of refugees and so on. In Israeli side, the establishment of Israeli state is legal due to the historical memory and myth that they have constructed by themselves. ${ }^{32}$ Furthermore, Palestinian protests and also Arabs and other Muslims would be accused as a kind of terrorism that threatens the Israeli security. This is exactly such a claim of securitisation that had been sounded loudly by a leader of radical Islamists, Osama bin laden. ${ }^{33}$ Although many states in the world through an international body of the United Nations have facilitated a conflict resolution, due to strong rejections and negations from both sides, until now it becomes a longlasting conflict. ${ }^{34}$

${ }^{32}$ Hillel Frisch and Shmuel Sandler, "Religion, state and the international system in the Israeli-Palestinian conflict," International Political Science Review 25, no. 1 (2004): 77-96; Michal Reifen Tagar, G. Scott Morgan, Eran Halperin, and Linda J. Skitka, "When ideology matters: Moral conviction and the association between ideology and policy preferences in the Israeli-Palestinian conflict," European Journal of Social Psychology 44, no. 2 (2014): 117-125.; Barak Mendelsohn, "Israel and its messianic right: Path dependency and state authority in international conflict," International Studies Quarterly 60, no. 1 (2016): 47-58.

${ }^{33}$ Anne Birgitta Nilsen, "Shaykh Osama Bin Laden: An evolving global myth," in eds. Islamic Myths and Memories, eds. Weismann, Sedgwick, Martensson (London: Routledge, 2016), pp. 139-160.

34 Ghada H. Talhami, "The conundrum of the Palestinian, two-state, one-state solution," Arab Studies Quarterly 38, no. 2 (2016): 468-480; Avi
This American policy in supporting Israel relatively has impacted on issues of oil, securitisation of Islam and nuclear weapons. The case of oil embargo by some Arab states could be considered as an evidence of this argument. ${ }^{35}$ Indeed, it disturbed the American interest at that time. In addition, this policy has influenced of the growth of Islamist extremism in many countries, mainly in Palestine and other Muslim countries. ${ }^{36}$ For Iran, the issue of Palestine could be instrumentalized as an anti-American legitimation. ${ }^{37}$ However, it does not mean that Israel has merely resulted in being a burden for the US. With their highly sophisticated military technology, Israel now is an important state that is able to support America in stabilizing balances of powers in the region. ${ }^{38}$ When the US have to challenge the anti-American sentiment in the region, Israel is their best friend. In the case of the proxy war in Syria, the US have not fought alone against Bashar al-Assad, Iran, Hizbullah and Russia, but they have been supported by Israel, Saudi Arabia and their other allies in the region, and also their European friends such as British and French.

Therefore, the American policy of supporting Israel has influenced their economic and national security interest, such as oil

Shlaim, "The rise and fall the Oslo peace process," in International Relations of the Middle East, ed. Louis Fawcett (New York: Oxford University Press, 2016), pp. 285-303.

${ }^{35}$ Nathaniel D. Sher, "The 1973 Oil Embargo and US-Saudi Relations: An Episode in New Imperialism" (PhD Thesis, Oberlin College, 2017).

${ }^{36}$ Sivan Hirsch-Hoefler, Daphna Canetti and Ehud Eiran, "Radicalizing religion? Religious identity and settlers' behaviour," Studies in Conflict \& Terrorism 39, no. 6 (2016): 500-518.

37 Vali Nasr, "Iran among the ruins: Tehran's advantage in a turbulent Middle East," Foreign Affairs 97, no. 2 (2018): 108-118.

${ }^{38}$ Michael Hudson, "The United States in the Middle East," pp. 356-379. 
matters, war on terrorism and securitisation of nuclear weapon proliferation in the region. This does not flow in one way, but rather two reciprocal ways which significantly give influences each other. In this situation, Israel cannot be viewed only as an ideological burden of the US, but also an important power that can be able to support the US security policy and economic interest.

\section{Multiple layers of complexities}

The reality of multiple layers of complexities has conditioned any American interest to be dynamic. Consequently, the level of difficulties in understanding the larger pattern of this American interest in the Arab Gulf region is very high. In general, however, this interest can be described by both economic and ideological matters that have influenced each other. The process of penetrating influences has occurred in three main levels of complexities, those are: national, regional and international.

The national complexities show the nature and character of each Arab Gulf country and also its socio-political and cultural dynamics within the country. Meanwhile, the regional complexities are the dynamics in a broader level that have been influenced by internal conditions and situations of each country and also interstate relations. Both national and regional complexities have related to the international level of complexities, where global powers (states) have had also their own special strategic cultures. All of them have been involved in more complex relations and interactions in the political constellations that relatively have been linked to the American interest as one of influential agencies of multipolarity of the global politics.

Furthermore, the character of strategic culture of every state has been shaped by essential elements of geography and natural resources (they describe physical, material, economic and political powers), ${ }^{39}$ the history of the state and its experience, ${ }^{40}$ its political system and structure, ${ }^{41}$ its perception of security and threat, ${ }^{42}$ and other external elements (such as regional and international balances of powers, global economic contexts, globalisation, and massive socio-political and cultural changes). ${ }^{43}$ These elements, for example, show explanations of why Saudi Arabia is different from Iran, America, Russia, China and other states in the Arab Gulf region.

In the specific context of the Arab Gulf, Saudi Arabia, for instance, is politically authoritarian and indeed, patrimonial, and economically practicing rentierism. It makes this

39 Yoel Guzansky, "Lines drawn in the sand: Territorial disputes and GCC unity," Middle East Journal 70, no. 4 (2016): 543-559.

40 J.E. Petersen, "The historical pattern of Gulf security," in Security in the Persian Gulf: Origins, Obstacles, and the Search for Consensus, eds. Gary

G. Sick and Lawrence G. Potter (New York: Palgrave, 2002); David Commins, The Gulf States: A Modern History (London: IB Tauris, 2012).

41 G. Power, "The difficult development of parliamentary politics in the Gulf: Parliaments and the process of managed reform in Kuwait, Bahrain and Oman," in The Transformation of the Gulf: Politics, Economics and the Global Order, eds. David Held and Kristian Ulrichsen (London: Routledge, 2012), pp. 29-46; Amin Saikal, "The Islamic order," in Iran at the Crossroads (Cambridge: Polity Press, 2016), pp. 38-71.

42 Arleigh H. Cordesman and Khalid R. Al-Rodhan, Gulf Military Forces in an Era of Asymmetric War (Washington; London: CSIS and Praeger Security International, 2007); Judith Yaphe, "Gulf security perceptions and strategies,” pp. 37-60.

${ }^{43}$ Richard Sokolsky and Eugene Rummer, "The role of outside powers," in The United States and the Persian Gulf: Reshaping Security Strategy for the Post-Containment Era, ed. Richard Sokolsky (Washington, DC: National Defence University Press, 2003), pp. 117-144; Matteo Legrenzi and F. Gregory Gause III, "The international politics of the Gulf," in International Relations of the Middle East, ed. Louis Fawcett (New York: Oxford University Press, 2016). pp. 304-323. 
country has had to determinedly renew its perception of the threat. It can be certainly seen that political movements such as Muslim Brotherhood (Ikhwan al-Muslimin), rebels of Baathism, al-Qaeda and other groups which totally have appreciated the spirit of Arab Spring tend to be perceived its threats. Iran with its friskily political manoeuvres in the region, especially its attempts of nuclearization, in addition, strongly has determined Saudi Arabia's foreign policy to enhance enmity towards its competitor. In order to implement its policy, this country has led GCC as its allies to face the most challenging political player in the region (Iran), despite the fact that Qatar distinctively has played its roles in balancing regional powers in a way of supporting Muslim Brotherhood and its political involvements in various Arab countries. In short, as a consequence, Qatar is relatively not accepted as one of its (Saudi) regional allies. In a wider regional political contestation (Middle East), countries which have resisted Muslim Brotherhood such as Egypt, Jordan, and others tend to become Saudi's additional supporters. With the exception of the Israel's roles in waging war against Hamas as the Palestinian branch of Muslim Brotherhood, Saudi Arabia has supported Israel due to pragmatically try to convince the US emphasizing Saudi is the proponent of its foreign policy (defending Israel). In the context of the global political contestation, Saudi Arabia has seemed to be the closest ally of the US. This country has needed to be militarily supported and advanced by the US, mainly to show its regional opponents that it has had superior military strength. The US itself in this context, has intended to challenge other global contestants such as Russia and China which have delighted to join in political games in the region. While both these prominent contestants in some cases have supported Iran, Saudi has perceived them greater threats as the US has done as well. Thus, with its all complexities (national, regional and global), it has no doubted that the US has chosen Saudi Arabia and politically instrumentalized it in order to achieve its political goals.

Furthermore, relations based on interest (oil, terrorism, nuclear and Israel) and states' complexities in the region have brought into conceptual and theoretical implications. In dealing with these implications, both basic arguments of the American interest - serving economic and ideological interests - should be linked together. However, it cannot bring us the conclusion of American imperialism. Oversimplification on the interrelated complexities cannot cover every single detail of elements of strategic culture of the state, complex inter-state relations in the region and the global world, and many others. Indeed, it is not as deep as philosophical elaborations, but rather emphasizing an academic effort of examining the complexities of strategic culture that have connected with matters of American interest in the Arab Gulf region. This is also the reason of giving an illustration of Syrian war, that mainly seems to avoid to result in such an oversimplified conclusion. ${ }^{44}$

Thus, both American economic and ideological interest in the Arab Gulf region have engaged each other; they have conditioned and been conditioned by multiple levels of strategic culture. Conceptually, it shifts the thesis that states that the American interest in the region is only for economic or ideological matter, and rejects the oversimplified argument of American imperialism.

\footnotetext{
${ }^{44}$ F. Gregory Gause, "Understanding the Gulf states: Why the monarchies of the Persian Gulf fall out and get back together and why it matters for the region and the world," Democracy: A Journal of Ideas 36 (2015). https://democracyjournal.org/magazine/36/understan ding-the-gulf-states/.
} 


\section{Conclusion}

On the one hand, the American oil policy in the Arab Gulf influences the matters of national security of the states in the region. On the other hand, its policy on the securitisation of Islam, the weapon of mass destruction and the protection of Israeli state counted as an ideological matter that has impacted on the economic policy.

It can be argued that the American policies in the region represent two larger directions of its interest, namely economy and ideology. Both have linked together and interrelatedly have determined and been determined by strategic culture of states and its multiple level of complexity (national, interstate, regional and international).

Therefore, this argument tends to stand against any oversimplified analysis of American interest which merely highlights either the matter of economy or ideology.

\section{Acknowledgment}

I owe thanks to Professor James Piscatori's greatly valuable contributions and insights during the process of research at the Centre for Arab and Islamic Studies (CAIS), the Australian National University (ANU), Canberra, Australia.

\section{References}

Ali, T. (2003). The Clash of Fundamentalisms: Crusades, Jihads and Modernity. London: Verso.

Atwan, A.B. (2007). Secret History of alQa'ida. London: Abacus Books.

Bin Laden, U. (2009). Declaration of war against the Americans occupying the Land of the Two Holly Places. In Euben, R.L., and Zaman, M.Q., eds. Princeton Readings in Islamist Thought: Texts and Contexts from Al-Banna to Bin Laden. New Jersey: Princeton University Press, pp. 436-459.
Borger, Julian. (2012). "US Military Chiefs Warn Israel Against Strike on Iran: Raid could Cut Off Support from America's Arab Allies Fears Attack on Nuclear Site would Worsen Unrest," The Guardian. London.

Chomsky, N. (2010). Hopes and Prospects. London: Penguin Books.

Ciftci, S., and Tezcür, G.M. (2016). Soft power, religion, and anti-Americanism in the Middle East. Foreign Policy Analysis, 12(3): 374-394.

Ciftci, S., O'Donnell, B.J., and Tanner, A. (2017). Who favors al-Qaeda? AntiAmericanism, religious outlooks, and favorable attitudes toward terrorist organizations. Political Research Quarterly, 70(3): 480-494.

Commins, D. (2012). The Gulf States: A Modern History. London: IB Tauris.

Cooper, A.S. (2012). The Oil Kings: How the US, Iran, and Saudi Arabia Changed the Balance of Power in the Middle East. New York: Simon and Schuster.

Cordesman, A.H. (2018). Bahrain, Oman, Qatar, and the UAE: Challenges of Security. New York: Routledge.

Cordesman, A.H., and Al-Rodhan, K.R. (2007). Gulf Military Forces in an Era of Asymmetric War. Washington; London: CSIS and Praeger Security International.

Economist Intelligence Unit (2002). “America and the Arabs -the War Against Terrorism." The Economist (London) 362, no. 8265 .

El Fadl, K.A. (2001). Islam and the theology of power. Middle East Report, 221: 28-33.

Ellis, S., and Futter, A. (2015). Iranian nuclear aspirations and strategic balancing in the Middle East. Middle East Policy, 22(2): 80-93.

Eltagouri, M. (2018). Tens of thousands of people have protested in Iran. Here's why. The Washington Post, [Online] 3 
January. Available at: https://www.washingtonpost.com/news/ worldviews/wp/2018/01/03/tens-ofthousands-of-people-protested-in-iranthis-week-hereswhy/?noredirect $=$ on\&utm_term $=.9 \mathrm{f} 844 \mathrm{e}$ 735421 [Accessed 21 April 2018].

Eroukhmanoff, C. (2018). It's not a Muslim ban! Indirect speech acts and the securitisation of Islam in the United States post-9/11. Global Discourse, 8(1): 5-25.

Fouskas, V and Gökay, B. (2005). The New American Imperialism: Bush's War on Terror and Blood for Oil. London: Praeger Security International.

Frisch, H., \& Sandler, S. (2004). Religion, state and the international system in the Israeli-Palestinian conflict. International Political Science Review, 25(1): 77-96.

Gardner, H. (2017). American Global Strategy and the 'War on Terrorism'. London: Routledge.

Gardner, Hall. (2007). Averting Global War: Regional Challenges, Overextension, and Options for American Strategy. New York: Palgrave Macmillan.

Gause, F.G. (2010). The Gulf war and the 1990s. The International Relations of the Persian Gulf, Cambridge: Cambridge University Press, pp. 88-135.

Gause, F.G. (2015). Understanding the Gulf states: Why the monarchies of the Persian Gulf fall out and get back together and why it matters for the region and the world. Democracy: $A$ Journal of Ideas, 36. [Online]. Available at:

https://democracyjournal.org/magazine/ 36/understanding-the-gulf-states/ [Accessed 20 April 2018].

Gendzier, I.L. (2015). Dying to Forget: Oil, Power, Palestine, and the Foundations of U.S. Policy in the Middle East. New York: Columbia University Press.

Gharehbaghian, M. (1987). Oil revenue and the militarisation of Iran: 1960-1978. Social Scientist, 15(4/5): 87-100.

Glaser, A., Mian, Z., Mousavian, S.H., and von Hippel, F. (2015). Building on the Iran deal: Steps toward a Middle Eastern nuclear-weapon-free zone. Arms Control Today, 45(10): 14-20.

Graham, C., and Riley-Smith, B., (2018). Syria airstrikes: US warns it is 'locked and loaded' if Assad uses chemical weapons again. The Telegraph. [Online] 14 April. Available at: https://www.telegraph.co.uk/news/2018/ 04/14/syria-airstrikes-donald-trump-setmake-announcement-military/ [Accessed 17 April 2018].

Guzansky, Y. (2016). Lines drawn in the sand: Territorial disputes and GCC unity. Middle East Journal, 70(4): 543-559.

Hartung, W. (2018). Trends in major US arms sales in 2017. Security Assistance Monitor. [Online]. Available at: https://securityassistance.org/sites/defaul t/files/US\%20Arms\%20Sales\%202017 [Accessed 20 April 2018].

Hegghammer, T. (2006). Global jihadism after the Iraq war. The Middle East Journal, 60(1): 11-32.

Hirsch-Hoefler, S., Canetti, D., \& Eiran, E. (2016). Radicalizing religion? Religious identity and settlers' behaviour. Studies in Conflict \& Terrorism, 39(6): 500-518.

Hudson, M.C. (2016). The United States in the Middle East. In Fawcett, L., ed. International Relations of the Middle East. New York: Oxford University Press. pp. 356-379.

Immerman, R.H. (2010). Empire for Liberty: A History of American Imperialism from Benjamin Franklin to Paul Wolfowitz. 
Princeton; Oxford: Oxford University Press.

Jiang, Z. (2017). Confrontations on the issue of terrorism between Iran and the US after 1979. Terrorism and Political Violence, 29(2): 236-253.

Jo, D.J., and Gartzke, E. (2007). Determinants of nuclear weapons proliferation. Journal of Conflict Resolution, 51(1): 167-194.

Johnson, Thomas A. (2012). Power, National Security, and Transformational Global Events: Challenges Confronting America, China, and Iran. Boca Raton: CRC Press/Taylor \& Francis.

Kraemer, T.D. (2006). Addicted to oil: Strategic implications of American oil policy. Strategic Studies Institute, U.S. Army War College. [Online]. Available at: http://www.strategicstudiesinstitute.arm y.mil/pdffiles/PUB705.pdf [Accessed 19 April 2018].

Legrenzi, M. \& Gause III, F.G. (2016). The international politics of the Gulf. In Fawcett, L., ed. International Relations of the Middle East. New York: Oxford University Press. pp. 304-323.

Little, D. (2009). American Orientalism: The United States and the Middle East since 1945. Chapel Hill: The University of North Carolina Press.

McMillan, J. (2003). US interest and objectives. In Sokolsky, R.D., ed. The United States and the Persian Gulf: Reshaping Security Strategy for the PostContainment Era. Washington, DC: National Defence University Press. pp. 9-36.

Mearsheimer, John J. and Stephen M. Walt. (2007). The Israel Lobby and U.S. Foreign Policy. New York: Farrar, Straus and Giroux.

Mendelsohn, B. (2016). Israel and its messianic right: Path dependency and state authority in international conflict.
International Studies Quarterly, 60(1): 47-58.

Nasr, V. (2018). Iran among the ruins: Tehran's advantage in a turbulent Middle East. Foreign Affairs, 97(2): 108-118.

Nilsen, A.B. (2016). Shaykh Osama Bin Laden: An evolving global myth. In Weismann, Sedgwick, Martensson, eds. Islamic Myths and Memories. London: Routledge. pp. 139-160.

Okruhlik, G. (2002). Networks of dissent: Islamism and reform in Saudi Arabia. Current History, 101(651): 22-28.

Pelletierre, S.C. (2004). America's Oil Wars. Westport: Praeger Publishers.

Petersen, J.E. (2002). The historical pattern of Gulf security. In Potter, L.G., and Sick, G.G., eds. Security in the Persian Gulf: Origins, Obstacles, and the Search for Consensus. New York: Palgrave.

Pour, P.S. (2017). The impact of Iran phobia on arms race in Persian Gulf After 2001. Journal of History Culture and Art Research, 6(1): 73-80.

Power, G. (2012). The difficult development of parliamentary politics in the Gulf: Parliaments and the process of managed reform in Kuwait, Bahrain and Oman. In Held, D., and Ulrichsen, K., eds. The Transformation of the Gulf: Politics, Economics and the Global Order. London: Routledge. pp. 29-46.

Rasler, K. (1996). Concessions, repression, and political protest in the Iranian revolution. American Sociological Review, 61(1): 132-152.

Roth, A., and Ellis-Petersen, H. (2018). Vladimir Putin calls US-led Syria strikes an act of aggression. The Guardian.

[Online] 14 April. Available at: https://www.theguardian.com/world/201 8/apr/14/insulting-russia-furious-oversyria-attacks-as-politician-likens-trumpto-hitler [Accessed 17 April 2018]. 
Ruehsen, M.D.M. (1993). Operation 'Ajax' revisited: Iran, 1953. Middle Eastern Studies, 29(3): 467-486.

Rutledge, I. (2005). Addicted to Oil: America's Relentless Drive for Energy Security. London; New York: IB Tauris.

Said, E.W. (1994). Culture and Imperialism. London: Vintage.

Said, E.W. (2003). Orientalism. London: Penguin Books.

Said, E.W. (2007). Covering Islam. London: Vintage.

Saikal, A. (2016). The Islamic order, Iran at the Crossroads. Cambridge: Polity Press.

Sher, N.D. (2017). The 1973 Oil Embargo and US-Saudi Relations: An Episode in New Imperialism. $\mathrm{PhD}$ Thesis, Oberlin College.

Shlaim, A. (2016). The rise and fall the Oslo peace process. In Fawcett, L., ed. International Relations of the Middle East. New York: Oxford University Press. pp. 285-303.

Smith, C. (2016b). The Arab-Israeli Conflict. In Fawcett, L., ed. International Relations of the Middle East. New York: Oxford University Press, 259-284.

Smith, G.F. (2016a). Big Israel: How Israel's Lobby Moves America. Washington, DC: Middle Eastern Policy, Inc.

Snow, D.M. (2016). The Middle East, Oil, and the U.S. National Security Policy. Maryland: Rowman and Littlefield.

Sokolsky, R.D., and Rummer, E.B. (2003). The role of outside powers. In Sokolsky, R.D., ed. The United States and the Persian Gulf: Reshaping Security Strategy for the Post-Containment Era. Washington, DC: National Defence University Press, 117-144.

Sultana, A. (2017). Taliban or terrorist? Some reflections on Taliban's ideology. Politics and Religion Journal, 3(1): 7-

24.
Tagar, M.R., Morgan, G.S., Halperin, E., and Skitka (2014). When ideology matters: Moral conviction and the association between ideology and policy preferences in the Israeli-Palestinian conflict. European Journal of Social Psychology, 44(2): 117-125.

Talhami, G.H. (2016). The conundrum of the Palestinian, two-state, one-state solution. Arab Studies Quarterly, 38(2): 468-480.

Vitalis, Robert. (2007). America's Kingdom: Mythmaking on the Saudi Oil Frontier. Stanford, Calif: Stanford University Press.

Yaphe, J.S. (2003). Gulf security perceptions and strategies. In Sokolsky, R.D., ed. The United States and the Persian Gulf: Reshaping Security Strategy for the Post-Containment Era. Washington, DC: National Defence University Press. pp. 37-60.

Zalloum, A.Y. (2007). Oil Crusades: America through Arab Eyes. London: Pluto Press. 